\title{
Annotated English translation of Mereschkowsky's 1905 paper ‘Über Natur und Ursprung der Chromatophoren im Pflanzenreiche'*
}

\author{
WILLIAM MARTIN ${ }^{1}$ AND KLAUS V. KOWALLIK ${ }^{2}$ \\ ${ }^{1}$ Institut für Genetik, Technische Universität Braunschweig, Spielmannstrasse 7, D-38023 Braunschweig, Germany \\ ${ }^{2}$ Botanisches Institut, Heinrich-Heine-Universität Düsseldorf, Universitätsstrasse 1, D-40225 Düsseldorf, Germany
}

(Received and accepted 15 May 1999)

\section{Introduction}

That plastids were once free-living cyanobacteria is now taken for granted by many, and for good reasons, for there is a wealth of data - in particular from the comparison of plastid and cyanobacterial genomes - that support this view. There is currently no seriously entertained alternative hypothesis to the view that plastids descend from cyanobacteria. But that was not always the case. Well into the 1970s there was a generally favoured alternative hypothesis, namely that early in evolution plastids arose de novo from within a non-plastid bearing cell (an autogenous origin) rather than through invasion by a cyanobacterium into a non-plastid-bearing cell with subsequent intracellular coexistence and reduction to an organelle (an endosymbiotic origin). Interestingly, the shift from autogenous to endosymbiotic hypotheses during the 1970s was a reversal of state for during the first two decades of this century, the endosymbiont hypothesis for the origins of plastids (and mitochondria, which will not be further discussed here) was very popular among biologists. It fell into disfavour shortly after the First World War, for reasons that are very difficult to summarize briefly, and remained scorned for 50 years (see Sapp, 1994, for an historical account in English, and Höxtermann, 1998, for a succinct historical account in German). So where did the first version of the endosymbiont hypothesis come from? In a nutshell, it came from Konstantin Sergejewiz Merezkovskij (usually written as Constantin Mereschkowsky), a Russian botanist of little standing who worked at a rather small and by no means prominent university in Kasan and who published a very remarkable paper in 1905. We are not aware of any true precedent for his paper, which draws upon three lines of evidence known at the time.

\footnotetext{
* Note: If Mereschkowsky is to be cited from this translation, the citation should read: Mereschkowsky, C. (1905). Über Natur und Ursprung der Chromatophoren im Pflanzenreiche. Biol. Centralbl., 25 : 593-604. English translation in Martin, W., Kowallik, K. V. (1999). Annotated English translation of Mereschkowsky's 1905 paper 'Über Natur und Ursprung der Chromatophoren im Pflanzenreiche'. Eur. J. Phycol., 34: 287-295.

Correspondence to: William Martin. Tel: +49531391 5785. Fax: +49 531391 5765. e-mail: w.martin@tu-bs.de
}

The first line of evidence was the known principle of symbiosis (Latin, 'living together'), the notion that two different organisms can stably coexist and in doing so may even give rise to a new type of organism. This concept can be traced to the Swiss botanist Simon Schwendener (1867), who discovered that lichens are a consortium of two organisms, a fungus and a photosynthesizer, that coexist in a very intimate and complex manner. The German botanist Heinrich Anton de Bary (1878) coined the term symbiosis to designate this type of coexistence. In the original sense, symbiosis did not carry the connotation of mutual benefit that it (usually) does today.

The second and, for his argument, probably most important line of evidence leads from the prior findings of the Swiss botanist Carl Wilhelm von Nägeli (1846) and the German botanists Leopold Kny (1871), Friedrich Schmitz (1883) and Andreas Franz Wilhelm Schimper (1883, 1885) that plastids proliferate through division. Nägeli, for example, noted (p. 111, translation by the authors): 'I have observed the division of green pigment-droplets in algae (e.g. Bryopsis Balbisiana, Valonia ovalis), in the prothallium of ferns and in Nitella. This division is manifested such that one can detect a constriction about the circumference that proceeds inward and ultimately divides the pigmentdroplets in two'. He described plastid division in Nitella in considerable detail. Kny argued plastid division to be a general attribute of plants. Schmitz described plastid division in great detail for the plastids of various algae. Schimper provided observations to suggest that the plastids are passed on from generation to generation through the female gamete. In one of the more famous pieces of botanical fine print, Schimper (1883) surmised in a footnote that translates: 'If it can be conclusively confirmed that plastids do not arise de novo in egg cells, the relationship between plastids and the organisms within which they are contained would be somewhat reminiscent of a symbiosis. Green plants may in fact owe their origin to the unification of a colourless organism with one uniformly tinged with chlorophyll'. That was neither a particularly bold nor a thoroughly argued case for an origin of plastids from cyanobacteria, but the notion was there, as are many ideas in the fine print of the last century.

The third, and unquestionably most novel, line of 
evidence came from comparing the physiological attributes of plastids and cyanobacteria known at the time.

So without further ado, we would like to present our English translation of that paper, which was published in German. We have not put more meaning into his paper than it originally contained; we also believe we have not missed anything crucial. The page breaks (e.g. [p. 594]) indicated in this document designate the beginning of a new page and correspond at the level of sentences one-toone with the original. Any emphasis (indicated by SMALL CAPITALS) is from the original only. To avoid confusion of footnotes, only the original footnotes are given. A few passages are reproduced in brackets [x], giving the original German or an occasional minor comment. The original does not contain brackets.

\title{
Über Natur und Ursprung der Chromatophoren im Pflanzenreiche
}

\section{[On the nature and origin of chromatophores (plastids) in the plant kingdom]}

\author{
By C. Mereschkowsky \\ Privatdozent at the Imperial University in Kasan
}

\section{Introduction}

According to currently accepted views, the chromatophores of plants are to be regarded as organs, i.e. as structures that in some manner unknown to us have gradually differentiated out of the otherwise colourless plasm of the cell body. WiLson (1902), for example, states: 'In the plants the plastids are almost certainly to be regarded as differentiations of the protoplasmic substance'. And the same assertion can be found in almost every textbook of botany, often stated in much more resolute terms.

That this notion is, by no means, a finding supported by direct observation, but rather that it can be viewed as just a theory, is self-evident. For no one to date has succeeded in observing such a differentiation of colourless plasm into green chromatophores, or into any kind of plastid for that matter.

If we ask ourselves how, in spite of that, this general conviction arose, we find a quite natural explanation in the long-known finding that certain [p. 594] colourless parts of the plant that do not contain chlorophyll to begin with will tend to green upon contact with light; this is true, for example, for colourless tissue at shoot tips (apical meristem), also in embryonal tissues or in underground rhizomes, etc. All these findings leave no doubt that the $d e$ novo origin of chlorophyll is indeed commonplace.

And because the chlorophyll arises de novo, it has seemed compelling to assume that in each case the carriers of chlorophyll, the chromatophores, also arise de novo.

But the very foundation was pulled out from under this old theory as SCHIMPER (1885), in his classical paper on chromatophores, demonstrated that although chlorophyll arises de novo in such cases, its carriers - the plastids [-] are already present to begin with in the colourless parts of the plant as tiny colourless leucoplasts, in other words that the plastids never appear de novo. But the traditional interpretation that chlorophyll bodies are differentiation products, i.e. organs of the cell, was so deeply engrained, that even after SCHIMPER's discovery, this theory, though left hanging in thin air, continued to be regarded as valid.

If one inquires about the basis that supposedly supports this view, one is met with utter silence. And that is not surprising, because there is no basis.

It is a firmly demonstrated and generally accepted finding that chromatophores do not differentiate out of colourless protoplasm, rather that they always arise from pre-existing, albeit sometimes colourless plastids (leucoplasts). Proponents of the theory that plastids are organs would therefore have to take refuge in a hypothesis entailing the assumption that although plastids do not arise de novo today, there must have been a time where cells possessed the ability to differentiate chromatophores from the protoplasm, and that these differentiation products then proliferated by division in uninterrupted continuity, such that contemporary chromatophores would be the direct descendants of such ur-chromatophores. The differentiation theory could thus be saved. But the completely unfounded theory of contemporary differentiation would then have to be replaced by a theory of ancient differentiation.

However, such a hypothesis is, for two reasons, completely unacceptable. The first problem is that no explanation whatsoever is offered for why cells that were once capable of differentiating plastids out [p. 595] of their plasm ${ }^{1}$ should have completely lost the ability to do the same today.

The main reason, however, why this hypothesis is unacceptable, is that it is founded upon an error in logic. And those who would wish to maintain their view on the nature of chromatophores by such a construct would thereby reveal that they lack a proper grasp of the nature of heredity. Indeed, what do adherents of this view claim? They claim that the chromatophore is an organ of the cell.

But what is an organ?

\footnotetext{
${ }^{1}$ Furthermore, there is no reason to attribute such a capability to ur-cells.
} 
An organ is a discrete part of an organism that is destined for a particular functional role and that, either spontaneously (ontogenetically) or under external influence, ALWAYS ARISES DE NOVO FROM THE PRIMORDIA THAT LIE HIDDEN IN THE GERM PLASM. In this sense an eye, a heart, a leaf is an organ; also the cilia of infusoria, the bordered pits of tracheids, the stalks of sessile diatoms are organs. However, everything that does not originate from the germ plasm, but rather that is continuously passed from one generation to the next, is not an organ. If we do not adhere strictly to the above definition of the concept of an organ, we will invariably fall into a confusion of words and meanings that will surely lead us to erroneous conclusions.

Let us now imagine a cell in ancient times, one that possessed the ability to differentiate chromatophores from its cytoplasm. This ability cannot have just suddenly arisen. Indeed, we have to assume that this capability and/or the chromatophores must have developed gradually from generation to generation. But in order for this to have occurred, the capability to differentiate protoplasm must have become heritable; for only thus could each step towards manifestation of this ability have been supplemented and improved by the next. In other words, chromatophores, if they indeed were differentiated from the cytoplasm, must have become heritable.

But what is the meaning of becoming heritable? It means that the respective organ, be it in the form of determinants or otherwise, would be contained in the germ plasm, materially represented in it so to speak. And once a property or an organ is contained in the germ plasm, the organ then spontaneously appears in each new generation as a necessary result of the [p. 596] germ plasm structure. Therefore, if chromatophores appeared at some point in time as differentiated parts of the cytoplasm, then they must also today spontaneously arise de novo by differentiation from the plasm in each plant cell, or at least in the egg cell and spore. If that does not occur, then it is a strong argument that chromatophores never developed autogenously in the plasm and that they are not a product of differentiation, in other words: THEY ARE NOT ORGANS AND THEY NEVER HAVE BEEN.

If, however, chromatophores are not organs and if they never have been, then there remains only one possibility - to interpret these structures as organisms, as symbionts. We reached this conclusion by purely deductive means. Now let us turn to the inductive method.

As stated above, there is absolutely no firm basis for regarding chromatophores as organs. Let us now see whether there is any basis for regarding them as symbionts.

\section{The basis for my interpretation of chromatophores as symbionts}

Chromatophores are thus not organs that might have gradually differentiated out of the cytoplasm. They are foreign bodies, foreign organisms, that invaded the colourless plasm of the cell and entered into a symbiotic coexistence with it. The basis that justifies this view is put forth in the following.

\section{The continuity of chromatophores}

Chromatophores, as stated above, never arise de novo, rather, they always arise through division of pre-existing plastids, and since the latter in turn arise from pre-existing plastids, etc., we necessarily arrive at the logical conclusion that long ago the first chromatophore migrated into a colourless organism. In other words: this continuity of chromatophores serves as a strong argument that they are foreign bodies or symbionts.

One could then ask whether this continuity has been demonstrated to a sufficient extent. Voices can occasionally be heard that believe it necessary to doubt the truth of this statement; it has occasionally been pointed out that SCHIMPER was able to demonstrate the existence of colourless plastids (leucoplasts) in the egg cells of only a small number of phanerogams and that a much larger number of investigations is needed to be absolutely sure in this matter. However, this scepticism is not justified. In fact, if we consider all of the gametes that [p. 597] contain coloured chromatophores, that is the egg cells of the various green, brown and red algae, furthermore the auxospores of the diatoms, the zygospores of the conjugates, in addition to all of the isospores and zoospores that contain coloured chromatophores, and in particular the countless cases of spores of the bryophytes and the pteridophytes, all of which are green and therefore contain chromatophores, we then obtain such an enormous number of findings supporting the argument that plastids are directly transmitted from generation to generation, that no doubt about their continuity can exist any longer.

Well, of course anything whatsoever can be doubted. But to doubt the continuity of plastids would be unjustified to the same degree as it would be were we to doubt that all green leaves really possess the capability to assimilate $\mathrm{CO}_{2}$. For the number of green plants for which this has been experimentally tested is nowhere near the many thousands of cases where the continuity of chromatophores can be directly observed.

\section{Chromatophores are highly independent of the nucleus}

It has been determined through many experiments that the nucleus must be regarded as the centre of all constructive-metabolic processes that occur in the cell. If the nucleus is removed from the cell by whatever means, all of its synthetic-morphological processes terminate; the shells of the foraminifera, the cell wall of plants, the cilia of infusoria are no longer synthesized, the food particles in 
amoebae are no longer or only incompletely digested ${ }^{2}$ ). Only such destructive-metabolic processes as movement, respiration, etc., still occur in anucleate protoplasm. These observations then indicate that the plasm without the nucleus is not capable of generating substance in the synthetic manner, and that all organs of the cell are dependent upon the nucleus chemically as well as morphologically. These two categories of processes, chemical and morphological, are of course intimately connected; for as Claude BERNARD has so clearly shown, morphological processes are nothing other than the external manifestation of the underlying chemical processes. [p. 598] And thus no morphological synthesis can occur in an anucleate plasm lacking synthesis of substance.

Chromatophores constitute a notable exception to this rule. If a portion of a green plant cell is squeezed off by plasmolysis such that it remains anucleate, the chromatophores contained therein live on just as normally as those that remain in the nucleate portion (KLEBS ([sic]1887); they grow, they multiply through division, they assimilate $\mathrm{CO}_{2}$ and they produce synthetic starch grains (probably sugar first). In short, they do not behave as organs that are dependent upon the nucleus, rather as completely independent organisms. Even outside the plasm, chromatophores continue for a while to assimilate $\mathrm{CO}_{2}$, as can easily be demonstrated by the bacteria method. Also, certain enzymes, oxygenase for example, do not arise in the nucleus, like so many other ferments, rather in leucoplasts, as CHODAT and BACH (1904) have shown. Production of lipids is a very common process in the plant kingdom; but chromatophores produce very distinct lipids that are very different from those found in the cytoplasm. 'In turn an argument', notes SCHIMPER, 'that the chemical processes in chromatophores and cytoplasm (which is dependent upon the nucleus, C.M.) are quite distinct' (l.c.p. 195).

Thus, chromatophores can grow and divide independently of the nucleus, produce substances synthetically; in short they do not behave at all like organs, rather like independent organisms and must therefore be regarded as such or as symbionts.

\section{The complete analogy of chromatophores and zoochlorellae}

Chromatophores possess a complete analogy with zoochlorellae.
If we consider Amoeba viridis Leydy, not a single principal difference can be found between its zoochlorellae and the chromatophores of any given green alga. In both cases the respective structures are independent of the nucleus, in both cases they grow, divide and behave as independent organisms. Also, the zoochlorellae do not arise de novo in the animal tissue, rather they always arise through division of pre-existing individuals. The analogy is so complete that in Hydra viridis these structure are even found in the egg cell of the maternal organism and are passed on in this manner through the egg cell from generation to generation. We thus [p. 599] have the same continuity of zoochlorellae and zooxanthellae as we see with respect to chromatophores.

Such a complete analogy makes it extremely likely that chromatophores, just like zoochlorellae, represent independent organisms that have entered into symbiotic coexistence with colourless cells.

The only difference between the two structures is that zoochlorellae can live and divide outside the animal cell, whereas chromatophores quickly degenerate $\left[{ }^{3}\right]$. However, this difference does not conflict with the analogy described above when we recall that chromatophores migrated into the plasm of the first plant cell in very ancient times, and thus had time to adapt to this special environmental niche [sich diesen besonderen Lebensbedingungen anzupassen], whereas the zoochlorellae of such animals as infusoria, Hydra, Spongilla entered into symbiotic relationships only relatively recently, because across closely related species, some occur with zoochlorellae, others without. It is therefore not surprising that chromatophores have long since lost their ability to live independently. [Kein Wunder also, dass die Chromatophoren ihre Fähigkeit, selbständig zu leben, schon längst verloren haben.]

\section{There are organisms that we can regard as free-living chromatophores}

A theory such as the one suggested here would gain considerably in terms of plausibility if the existence of some free-living organisms with similarity to the symbionts could be demonstrated. The lower forms of the Cyanophyceae can indeed be viewed as such organisms. For the difference between a chromatophore and an Aphanocapsa or Microcystis is very slight, as seen in the following table.

\footnotetext{
2 See however Gruber (1904) who found that individuals of Amoeba viridis in which the nucleus had degenerated due to a fungal disease were still able to ingest green algae and apparently to digest them in the normal manner, as DANGEARD (1894/5) had previously observed.
}

\footnotetext{
3 Professor FAmintzin, who has considered this question and who, as I have heard, is also convinced of the independent nature of chromatophores, appears to have been unsuccessful to date in his attempts to cultivate chromatophores outside the cell, as he has been able to do in the case of zoochlorellae (1889). [The footnote indicator is missing in the original, but probably belongs here.]
} 
Cyanophyceae

(Aphanocapsa, Microcystis and the like)

1. Small, blue-green, round or oval bodies of very simple structure.

[p. 600]

Cyanophyceae

2. The green pigment saturates the plasm uniformly or is distributed therein in the form of very small droplets. ${ }^{4}$

3. Do not possess a true nucleus, rather just certain structures (nucleic granules) that can be viewed as a predecessor of the nucleus. ${ }^{5}$

4. Nutrition: assimilation of $\mathrm{CO}_{2}$ in the light.

5. Reproduction: through division.
Chromatophores

1. Small, green (probably blue-green originally, as with Cyanomonas), round or oval bodies of very simple structure.

Chromatophores

2. The green pigment saturates the stroma uniformly or is distributed therein in the form of very small droplets.

3. Do not possess a true nucleus, rather just certain structures (pyrenoids) that can be viewed as a transformed, primitive nucleus.

4. Nutrition: Assimilation of $\mathrm{CO}_{2}$ in the light.

5. Reproduction: through division.

${ }^{4}$ In my opinion, it is out of the question to discuss occurrence of chromatophores among cyanophytes; moreover, they are themselves chromatophores. For the outer plasm, which is equivalent to the cytoplasm of plant cells, is uniformly coloured, and in those cases where a thin, hyaline outer layer can be discriminated, the latter can probably be homologized to the cell wall of bacteria. To consider KoHL's (1903) small green droplets as chromatophores would lead us to speak of chromatophores in chromatophores! Indeed, A. MEYER (1895) has clearly shown that higher plants possess such green droplets embedded in colourless stroma, too.

${ }^{5}$ Among higher representatives of this group, true nuclei have of course been reported by KoHL, OLIVE, PHILLIPS and others.

As seen in this table, the similarity between these two structures is great and obvious [ganz auffallend gross]. The few differences are amply explained by the different surroundings in which these structures have existed since ur-times: cyanophytes live free in water, chromatophores live embedded in the cytoplasm.

In the special environmental niche of the symbiont, an outer wall was no longer as necessary as it is for free-living organisms, and it therefore might have been lost. Nucleic granules, which are found in such cyanophytes as Microcystis, Aphanocapsa and the like and which represent rudimentary nuclear primordia, could have been transformed in the course of time into pyrenoids, which ultimately became useless among the higher plants and therefore disappeared. The nature of the pigment has also changed somewhat and has, under the influence of the nucleus, become pure green. ${ }^{6}$ It is well known that the colour of the pigment easily changes among the cyanophytes (GERASSIMOFF 1902).

The strong similarity in appearance, in substance, and in means of proliferation of both structures thus makes it exceedingly likely that [p. 601] chromatophores are Cyanophyceae that invaded the plasma. That the other plastids (leucoplasts and chromoplasts) represent nothing other than transformed chromatophores has been amply demonstrated by SCHIMPER.

\section{Cyanophytes actually live as symbionts in cell protoplasm}

We have seen that sufficient grounds exist (No. 1 and No. 2) to regard chromatophores not as organs, but as foreign organisms that migrated into the cell. We have furthermore shown that the behaviour of chromatophores shows complete analogy with zoochlorellae, that unquestionably are foreign organisms. Finally we have shown that organisms exist in nature (the lower Cyanophyceae) that in all probability can be regarded as free-

\footnotetext{
6 That chromatophores were probably originally blue-green is shown by Cyanomonas americana, for details see below. This is also supported by the lack of pure green cyanophytes.
}

living antecedants of chromatophores [frei lebende Vorfahren der Chromatophoren]. But before we can regard our theory as thoroughly supported in all respects, we have to bring forth one last link in the chain of arguments [Kette der Beweise]. Namely, we have to show that cyanophytes can actually invade the cytoplasm and can continue to live there as symbionts.

And such phenomena are indeed very well known. As the first example, consider the rhizopod Paulinella chromatophora (LAUTERBORN 1895), which is parasitized by a cyanophyte. If the blue-green colour of this cyanophyte were to be transformed into green, we would be looking at a true chromatophore. A similar case can be seen in the flagellate Cyanomonas americana DAvis (DAvis 1894) that contains blue-green bodies. Finally we have the unusual case of a cyanophyte, Richelia intercellularis ScHM., that lives in symbiosis with a diatom, Rhizosolenia styliformis. How this cyanophyte got into the plasm of this diatom, the entire surface of which is surrounded by a silicaceous wall, is unknown (probably during a spore stage); but this finding shows how easily cyanophytes can enter into symbiotic coexistence with even such cells as are encapsulated by a cell wall.

\section{The significance of this symbiotic theory}

The theory developed here appears to me to have considerable significance, particularly in two respects.

A. Only with the help of this theory is it possible to correctly interpret and understand the origin and phylogeny of the plant kingdom.

1. According to this theory, the plant cell is nothing other than an animal cell with cyanophytes that have invaded it; as a consequence THE PLANT KINGDOM IS TO BE DERIVED FROM THE ANIMAL [p. 602] KINGDOM. The ur-plants were nothing other than amoebae or flagellates into which cyanophytes had migrated.

2. Because this process of invasion by various cyanophytes into various amoebae and flagellates took place 
repeatedly (as in the recent invasions of zoochlorellae and zooxanthellae), THE ORIGIN OF THE PLANT KINGDOM IS HIGHLY POLYPHYLETIC.

3. Because there are green, yellow and red cyanophytes, as is also the case for the direct antecedants of the cyanophytes, the bacteria, the three main branches of the plant kingdom - the green, the brown and the red algae [-] could have thus originated independently. Indeed, we are quite familiar with the green, the yellow, and the red flagellates, and no one would now doubt that the flagellates should be regarded as the organisms from which the higher forms of plants arose. Both zoospores and gametes, including antherozooids, represent precisely this flagellate stage. In the further evolution of the plant kingdom, this stage, which predominates among the flagellates, has been increasingly repressed, whereas the vegetative stage (spores) which in the past was barely manifest, has moved to the foreground. ${ }^{\text {? }}$

Regarding the origin of the two symbionts themselves, the cyanophytes and the animal cell, let it suffice to say that I will discuss this issue in a later contribution.

Here I just wish to note briefly that I have come to the conviction that life on Earth probably had a polyphyletic origin in that it must have arisen twice. Once as the water that covered the Earth's surface was still hot, namely in the form of tiny bacteria that gave rise to the micrococci, later the cyanophytes (as a side branch), and finally the true fungi (with the exception of the phycomycetes). And a second time, as the water had cooled down and as organic substrates had become available; here a very different, amoeboid kind of plasm arose (probably in the form of small Monera) that is homologous to the cytoplasm. [Und das zweitemal, als das Wasser schon abgekühlt war und bereits organische Nahrung vorhanden war; da entstand ein ganz verschiedenes, amoebenartiges Plasma (wohl in Form von kleinsten Moneren), das dem Cytoplasma homolog ist.] The latter was invaded by small micrococci which lived as symbionts and ultimately gave rise to the nucleus (the chromosomes?). The animal cell can thus be regarded as a simple symbiosis (cytoplasm and nucleus-micrococci), the plant cell as a double symbiosis (animal cell and cyanophytes). I distinguish, however, in addition to the animal and the plant kingdom, a third kingdom that is quite distinct from the others and strictly separated [p. 603] from them - the fungal kingdom. The latter does not represent a symbiosis, because here the nucleus arose as a differentiation product, as can still be observed today in Bacillus Bütschlii (Schaudinn 1902).

B. The symbiotic theory provides a much deeper understanding of the very nature of plants. All of the peculiarities that are characteristic for plants and that distingish them from animals, are revealed, in light of this theory, as the natural result of a symbiosis between an animal cell and a $\mathrm{CO}_{2}$-assimilating cyanophyte.

What distinguishes a plant from an animal?

7 See my theorem of the transmission of stages (MeresChKowsKY 1903).
1. Plant cells possess a firm cellulose wall; animal cells have none.

2. Animal cells require organic substrates which they can absorb in the form of solid particles; plant cells absorb only liquid substrates and require no preformed organic substances.

3. Plants possess neither muscular nor nervous system and as a consequence no awareness [psychisches Leben]; they are by nature passive. Animals are highly active.

From the standpoint of current predominating theory, namely that chromatophores are nothing more than differentiation products that arose within a colourless cell, how and why the evolution of life [die Entwicklung der Organismenwelt] embarked upon two directions so fundamentally different as those of the plant and animal world would be altogether incomprehensible.

The invasion by cyanophytes solves the problem of the origin of the plant kingdom, with all its peculiarities, in the clearest and most simple terms. The first of the three differences listed above is to be interpreted as a natural result of this invasion by cyanophytes, and the remaining two follow from the first, and, through strict logic, one from the other in turn, as easily seen from the following considerations.

1. Chromatophores can assimilate $\mathrm{CO}_{2}$ and can synthesize carbohydrates that are easily polymerized to cellulose, and plant cells obtained their cellulose cell wall thus. This permitted the development of strong turgor in the cell that, in turn, made it possible and advantageous to use this turgor to replace the outer and/or inner skeleton of animals.

2. This firm layer around the cell [feste Zellhaut] in turn made it impossible to absorb solid substrates; as such, plant cells were forced to nourish themselves through soluble substrates, that are indeed almost exclusively of mineral nature. [p. 604]

3. Plant cells receive WITH NO EFFORT WHATSOEVER large amounts of preformed organic substrates (carbohydrates), which their chromatophores willingly supply. For this reason plant cells do not need to exert the effort that animal cells must in order to locate organic substrates. It was in this manner that the passive, quiescent nature of the plant kingdom arose, with it the lack of muscular and nervous tissue and as a consequence the lack of awareness.

Let us imagine a palm tree, growing peacefully near a spring, and a lion, hiding in the brush nearby, all of its muscles taut, with bloodthirsty eyes, prepared to jump upon an antelope and to strangle it. The symbiotic theory, and it alone, lays bare the deepest mysteries of this scene, unravels and illuminates the fundamental principle that could bring forth two such utterly different entities as a palm tree and a lion. The palm behaves so peacefully, so passively, because it is a symbiosis, because it contains a plethora of little workers, green slaves (chromatophores) that work for it and nourish it. The lion must nourish itself.

Let us imagine each cell of the lion filled with chromatophores, and I have no doubt that it would 
immediately lie down peacefully next to the palm, feeling full, or needing at most some water with mineral salts.

\section{List of references}

Chodat et Bach, Aus dem Botanischen Centralblatte 1904.

DANGEARD, Le Botaniste 1894/5.

Davis, nach Oltmanns, Über Bau und Biologie der Algen 1904.

FAmintzin, Beitrag zur Symbiose von Algen und Tieren. Mémoires d. l'Acad. d. Sc. d. St. Pétersb. T. XXXVI, Nr. 16, 1889.

Gruber, Über Amoeba viridis. Zeitschrift für Morphologie und Systematik, 1904.

KLEBS, Untersuchungen aus dem bot. Institut zu Tübingen, Bd. II, 1887.

KoHL, Untersuchungen über Bau und Kernteilungen der Cyanophyceen, 1903.

LAUTERBORn, Protozoenstudien. Zeitschr. für wissenschaftl. Zoologie, Bd. 59, 1895.

MeYER, A. Untersuchungen über die Stärkekörner. Jena 1895.

Mereschrowsky, Loi de translation des stades. Journ. de Botanique, 1903.

Ostenfeld og J. Schmidt, Plankton from the Red Sea and the Gulf of Aden, Vidensk. Meddel. fra den naturh. Forening in Kbhvn. 1901.

SCHAudinN, Archiv für Protistenkund 1902.

SCHIMPER, Jahrbücher für wissenschaftliche Botanik, Bd. XVI, 1885.

Wilson, The cellule, 1902. [The quoted passage appears on p. 53 of The Cell in Development and Inheritance, 1902]

\section{Translators' notes}

We have used following words in translation, rather than the direct or dictionary translations (in parentheses) in order to convey the meaning that was quite obviousl intended and in order to make the text more accessible: Beweis, argument (proof); beweisen, demonstrate, indicate (prove); Cyanophycee, cyanophyte (cyanobacterium); Erscheinungen, processes (phenomena); spangrün, bluegreen (verdigris, a colour made with copper salts); Tatsache, finding (fact); vorstellen, represent (present); Zellmembran, cell wall (cell membrane); Zellplasma, cytoplasm (cell plasm); zugeben, assume (admit, concede).

Where we were not absolutely sure what was intended, we left it literal. One such example is 'Vererbung' which could either be Mendelian heredity or just simply heredity, we opted for 'heredity'. Mereschkowsky used the words Beweis (proof), beweisen (prove) or Tatsache (fact) where the modern meanings of argument, demonstrate and finding are intended. This has more to do with biology of the day than with Mereschkowsky's German, as can be seen with the use of 'Kette der Beweise' that also today means 'chain of arguments.' Translating directly would have lent the paper a dogmatic tenor that it does not have. The only literature predating Mereschkowsky's 1905 paper that explicitly suggests plastids to have perhaps descended from cyanobacteria - that we are aware of - is Schimper's casual (and possibly lucky-guess) footnote.

The passages on pp. 599-600 are particularly notable. They contain very explicitly the notion that the cyanobacterial symbiont should tend to undergo reduction in the cytosol of its host. The passage on pp. 602-603 is dramatically tragic. The independent origins of life sketched here is very obviously nothing other than an early statement of the differentness of prokaryotes and eukaryotes. But the beelzebub of differentiation that Mereschkowsky so meticulously isolated and exorcized from thoughts on plastid origins only a few pages prior is envoked there to explain the origin of the nucleus in the fungi, making them non-symbiotic descendants of bacteria in his scheme (also in his four-part series, 1910). Had he not invoked differentiation in this case either, he would have - in addition to having chiselled from logical granite the entire endosymbiotic theory-boldly drawn the natural dichotomy in the living world that separates prokaryotes and eukaryotes in the same twelve soonforgotten pages (something that did not occur for another several decades), be his views on the origin of the nucleus right or wrong.

The paper appeared in the September 15 issue (number 18). In the November 1 issue (number 21), a little-noted addendum to his essay appeared that, for the sake of thoroughness, should also be translated. It contains a notable conclusion that protein synthesis occurs in plastids.

\section{Nachtrag zu meiner Abhandlung: Über Natur und Ursprung der Chromatophoren im Pflanzenreiche}

By C. Mereschkowsky

Shortly after I delivered the aforementioned essay to the editors of Biologisches Centralblatt, I received the new and very important paper by A. FISCHER (1905) on the organization of cyanophytes, which prompts me to add a few comments to my contribution.

At the same time, I would like to take this opportunity to correct a few errors or inaccuracies that are contained in the essay, something that was my intent to do in the proofs, which I unfortunately never received. Thus, the literature is incomplete and in part inaccurate. ${ }^{1}$

\footnotetext{
1 The title of the paper by OLtmann, which was not available to me at the time of submission, was given only approximately, with the intent to
}

First, FisCHER's (1905) paper has very clearly and in a seemingly undoubtable [p. 690] manner resolved the longdebated question concerning the presence of a nucleus and chromatin granules in the cyanophytes, for the negative. This circumstance requires that I amend the passage in which I compare Cyanophyceae with chromatophores, namely the third point (p. 600), as follows:

3. Do not possess a true nucleus, rather just a certain colourless central mass, probably containing undetectably small chromatin granules.

correct it in proof. Also, a second paper by Professor FAMINTzIN that is of great importance to the issue should be cited. 
3. Do not possess a true nucleus, rather just a certain colourless central mass (pyrenoid), that can be viewed as a homologue of the central mass of the Cyanophyceae.

I would also like to change the fourth point in the following manner:

4. Nutrition: assimilation of $\mathrm{CO}_{2}$ in the light. Synthesis of protein.

4. Nutrition: Assimilation of $\mathrm{CO}_{2}$ in the light. Synthesis of protein. [Synthese von Eiweißstoffen.]

The reasons that motivate me to attribute this property of being protein synthesizers [diese Eigenschaft als Eiweissbildner] to chromatophores (plastids) will be elaborated in my next contribution. ${ }^{2}$

With regard to the continuity of plastids, I would like to point out that all seed plants contain chromatophores in their seeds, albeit colourless ones that subsequently green. This finding was debated long after Schimper whereby many observers including SACHS, HabeRLANDT, MiKOSCH, BeLZUNG were of the opinion that mature seeds do not contain chromatophores, rather that the latter originate from the colourless plasm during germination. Only through the thorough work of FAmINTZIN (1893) could it be conclusively demonstrated firstly, that the chomatophores persist as small, shriveled structures in the rich seeds [reiche Samen: this is probably a typo where ripe (reife) seeds was intended] and secondly, that the chromatophores of the seedlings develop exclusively from these. In this finding we have new and important support for the uninterrupted continuity of plastids.

\section{Typographical errors}

Page 599 3rd line from the bottom: Is instead of HAD

PAGE 600 21ST LINE FROM THE TOP: CENTRAL MASS instead of NUCLEIC GRANULES [p. 691]

Page 601 14th line from the bottom: after LIVES [styliformis in this translation] add (Ostenfeld AND SCHMIDT 1901)

Page 602 23rd from the top: [grammar, does not translate]

Page 603 9th from the top: sYMBIOSIS instead of sYMBIONT [corrected in this translation]

Page 604 2nd from the top: after CARBOHYDRATES add, PROBAbLY PROTEINS AS WELL

Page 604 in the literature: Oltmanns' Morphologie und Biologie Der Algen instead of Oltmanns Über Bau, etc.

\section{To be added to the list of references}

Famintzin, A., Über Chlorophyllkörner der Samen und Keimlinge. Mélanges biologiques. T. XIII. St. Petersburg 1893.

Fischer, A., Die Zelle der Cyanophyceen. Botanische Zeitung 1905.
Famintzin's work was notably emphasized in the addendum. Andrej S. Famintzin was a powerful professor at a prominent university (St Petersburg), unlike the author. Famintzin and Merschkowsky corresponded, and the former criticized the latter while laying claim to salient aspects of Mereschkowsky's conceptual advance (Sapp, 1994; Höxtermann, 1998). Höxtermann surmised (translation): 'After publication (1905) Merezkovskij harvested the criticism of Famincyn, who found neither the parallels between plastids and cyanobacteria, nor the analogy to zoochlorellae, which in contrast to plastids possess a nucleus and a cell wall, convincing. Famincyn did not address the issue of the ancestors of the organelles among contemporary algae and bacteria. In this matter, he evidently feared speculation and analogy to a greater extent than his more creative colleague did'.

Given the overall strength of Mereschkowsky's argument, one wonders how the notion that chloroplasts arose from cyanobacteria could have possibly fallen out of grace. It was hardly a translation problem since German was a standard scientific language. Furthermore, Ivan E. Wallin, an American professor, discussed the topic in English (1927), albeit only briefly, since he was primarily concerned with arguing the symbiotic origin of mitochondria. From today's standpoint, one scorching para- graph (pp. 738-739) in the 1928 third revised edition of Wilson's textbook (the same Wilson that Mereschkowsky challenged in his opening statement) stands out. Wilson was primarily concerned with the nucleus and categorically rejected Mereschkowsky's weakest argument, that for the symbiotic origin of the nucleus - but he did so viciously: '... Mereschkowsky ('10), in an entertaining fantasy, has developed the hypothesis ...[...]... in further flights of the imagination Mereschkowsky suggests...'. His concluding sentence, whether prophecy or curse, was painfully self-fulfilling: 'More recently Wallin ('22) has maintained that chondriosomes [mitochondria] may be regarded as symbiotic bacteria whose association with the other cytoplasmic components may have arisen in the earliest stages of evolution (p. 712). To many, no doubt, such speculations may appear too fantastic for present mention in polite biological society; nevertheless it is within the range of possibility that they may someday call for more serious consideration'. In that paragraph, a symbiotic origin of the nucleus was foresworn, and with it the whole of symbiotic hypotheses, including those involving plastids and mitochondria-but without a single substantiating argument. Had Constantin Mereschkowsky (1855-1921) been able to reply, the scientific setback might have lasted less than 50 years.

\footnotetext{
2 Organisms with chromatophores (green plants) synthesize proteins; Organisms without chromatophores (animals) require protein nourishment. - Widespread occurrence of protein crystals in chromatophores. - Probable origin of proteins in assimilating tissues (in green cells).
} 


\section{Acknowledgements}

We thank the Deutsche Forschungsgemeinschaft for financial support, John F. Allen for enriching discussions, Johannes Wöstemeyer for obtaining some difficult-to-get literature and Gustav Fischer Verlag, Jena, for permission to publish this translation.

\section{References}

DE BARY, A. (1878). Ueber Symbiose. Tageblatt der 51. Versammlung deutscher Naturforscher und Aerzte in Cassel, 121-126.

Höxtermann, E. (1998). Konstantin S. Merezkovskij und die Symbiogenesetheorie der Zellevolution. In Bakterienlicht und Wurzelpilz (Geus, A., editor), 11-29. Basiliken-Presse, Marburg/Lahn.

KNY, L. (1871). Ueber die Vermehrung der Chlorophyllkörner durch Zweitheilung und das allgemeine Vorkommen dieses Processes im Pflanzenreich. Sitzungsberichte der Gesellschaft naturforschender Freunde zu Berlin, 65-66.

MereschKowsKY, C. (1905). Über Natur und Ursprung der Chromatophoren im Pflanzenreiche. Biol. Centralbl., 25: 593-604 (addendum in 25: 689-691).
Mereschrowsky, C. (1910). Theorie der zwei Plasmaarten als Grundlage der Symbiogenesis, einer neuen Lehre von der Entstehung der Organismen. Biol. Centralbl. 30: 278-288, 289-303, 321-347, 353-367.

NÄGELI, C. (1846). Bläschenförmige Gebilde im Inhalte der Pflanzenzelle. Z. Wiss. Bot.. 3/4: 94-128.

SAPP, J. (1994). Evolution by Association: A History of Symbiosis. Oxford University Press, New York.

SCHIMPER, A. F. W. (1883). Ueber die Entwickelung der Chlorophyllkörner und Farbkörper. Bot. Zeit., 41: 105-113, 121-131, 137-146, 153-162.

SCHIMPER, A. F. W. (1885). Untersuchungen über die Chlorophyllkörner und die ihnen homologen Gebilde. Jahrb. Wiss. Bot., 16: 1-247.

Schmitz, F. (1883). Die Chromatophoren der Algen. Vergleichende Untersuchungen über Bau und Entwicklung der Chlorophyllkörper und analogen Farbstoffkörper der Algen. Verhandlungen des Naturwissenschaftlichen Vereins der Preussischen Rheinlande und Westfalen, 40: 1-180.

SCHWENDENER, S. (1867). Ueber die wahre Natur der Flechten. Verhandlungen der Schweizerischen Naturforschenden Gesellschaft in Rheinfelden, 51: 88-90.

Waluin, I. E. (1927). Symbionticism and the Origin of Species. Baillière, Tindall \& Cox, London.

WiLson, E. B. (1928). The Cell in Development and Heredity, 3rd revised edtion. Macmillan, New York. Reprinted (1987) by Garland Publishing, New York. 